\title{
Um poema e duas traduções Reinhart Buyno
}

ZAPEWNE GDZIEŚ SIĘ PONIEWIERA

Zapewne gdzieś się poniewiera poza twym łatwym zasiegiem ten najcenniejszy sekret rozwiązanie twej odletniej zagadki celebrowanej tajemnicy mimo że nawet mogłoby czychać gdzieś na północnym borze w gesstwinie złowieszczej daleko od tego co logicznie możnaby nazwać prawdą mimo że nawet leży pochowane na cuchnącym śmietniku lub na wieki zostało potępione w kanałach opuszczonych

- a powiedz nam tylko jak by to było jeśliby pewnego dobrego dnia jak niby nigdy nic tyś coś tam sobie dopatrzył w przeblysku spojrzenia na głębi oczu

których nigdyś przedtem nie urzar które tęsknią po cichu by zoztały wykryte i nagle byś na zawsze rozpoznar że oto twój sekret rozwiązanie odletniej zagadki oto tajemnica w tym cała - że tu masz skarb co zdala góruje nad złotem 


\title{
There is Always Somewhere
}

\author{
There is always somewhere \\ hidden form your daily reach \\ a most precious secret \\ the answer to your lifelong puzzle \\ to your sacred mystery \\ even though it might be lurking \\ in the darkest jungle \\ in a desperate thicket \\ distant from what otherwise \\ would be interpreted \\ as truth \\ it may lie even \\ at the bottom of a filthy dustbin \\ or be lost in the stench \\ of a dismal sewer \\ but what if one day you glimpse it \\ just like that \\ softly yearning to be discovered \\ in the eye of someone \\ you'd never met before \\ and you know of a sudden forever \\ it is the precious secret \\ the answer to your lifelong puzzle \\ to your sacred mystery \\ the very treasure \\ you cannot measure \\ in gold
}




\title{
Deve Sobrar em Algum Paradeiro
}

\author{
Deve sobrar em algum paradeiro \\ fora do alcance comum \\ algo como seu preciosíssimo segredo \\ a solução ao perene quebra-cabeças \\ ao mistério sagrado \\ poderia até estar à espreita \\ na mais escura floresta \\ na moita mais abjeta \\ distante do que de outro modo \\ interpretariam como pura verdade \\ inclusive até se esconder \\ no fundo duma nojenta lata de lixo \\ ou estar condenado \\ ao esquecimento num esgoto \\ Mas o que diriam \\ se um belo dia \\ você o encontrasse \\ nem mais nem mesmo \\ num relance \\ suavemente ansiando \\ ser descoberto \\ em um olhar jamais conhecido \\ e de repente você soubesse \\ para todo o sempre amém \\ que ali está \\ o preciosíssimo segredo \\ a solução ao perene quebra-cabeças \\ ao mistério sagrado \\ aquele mesmo tesouro \\ que não encontra preço em ouro
}

